\title{
IDENTIFIKASI KAYU DAN PERANANNYA TERHADAP PELESTARIAN BENDA CAGAR BUDAYA
}

\author{
Oleh \\ Ir. Yustinus Suranto, M.P \\ Dosen Fakultas Kehutanan Universitas Gadjah Mada, Yogyakarta
}

Tulisan ilmiah ini disusun untuk memenuhi permintaan yang datang dari Dewan Redaksi suatu jurnal yang diterbitkan oleh Balai Konservasi Peninggalan Borobudur yang berkantor di Jalan Badrawati Borobudur Magelang. Dewan Redaksi merencanakan untuk menitikberatkan penerbitan jurnal edisi ini dengan berorientasi pada topik Benda Cagar Budaya yang berbahan baku kayu.

Judul tulisan ilmiah sebagaimana tersaji di atas, merupakan judul yang dikehendaki oleh Dewan Redaksi, setelah dua orang anggota Dewan Redaksi pada awal September 2008 datang berkunjung di ruang kerja penulis di Fakultas Kehutanan UGM dan berbincang dengan penulis. Diharapkan agar tulisan ini dapat memberi sumbangan ilmiah bagi para arkeolog dan pejabat di lingkungan Balai Pelestarian Peninggalan Purbakala (BP3) di seluruh Indonesia yang memiliki tugas pokok dan kompetensi untuk memelihara benda cagar budaya. Di samping itu, tulisan ini juga dimaksudkan untuk memberi sumbangan bagi para pejabat pada Dinas Kebudayaan dan Pariwisata pada pemerintah daerah provinsi, kabupaten dan pemerintah kota madya di seluruh wilayan Indonesia mengingat bahwa dinas ini mendapat amanat dari negara (pemeringah dan dewan perwakilan rakyat) untuk memelihara, merawat dan memanfaatkan benda cagar budaya yang ada di wilayah administratif kerjanya, untuk kepentingan pengembangan budaya dan pariwisata.

Tulisan ilmiah ini akan disajikan di dalam sistematika tertentu, yaitu terdiri atas sub-sub judul: arti penting benda cagar budaya, keragaman benda cagar budaya, benda cagar budaya yang terbuat dari kayu, kerusakan benda cagar budaya yang berbahan kayu, upaya pelestarian benda cagar budaya, sumbangan ilmu identifikasi kayu di dalam pemugaran benda cagar budava yang berbahan kayu, Ilmu identifikasi kayu. Diharapkan, dengan sistematika penulisan yang demikian ini dapat membantu dan mempermudah bagi para pembaca untuk memahami isi dan misi vang dikandung di dalamnya.

Arti Penting Benda Cagar Budaya dan Nilai Budaya Unggul.

Bangsa Indonesia memiliki banyak benda cagar budaya yang tersebar di seluruh wilayah negara kesatuan Republik Indonesia, baik yang ada di wilayah perairan maupun di wilayah daratan Pada masing-masing Pulau Sumatera, Pulau Jawa, Pulau Bali, Pulaupulau di Kepulauan Nusa Tenggara, Pulau Kalimanatan, Pulau Sulawesi, Kepulauan Maluku dan Pupua, terdapat banyak benda cagar budaya. Setiap benda cagar budaya yang ada di masing-masing pulau tersebut memiliki keunikan, kekhasan dan kekhususan. Hal ini berkait dengan bahan, wujud, bentuk, periode waktu pembuatan serta latar belakang etnik dan budaya leluhur pembuat benda yang sekarang ini berstatus sebagai benda cagar budaya.

Setiap benda cagar budaya merupakan sumber daya budaya bagi etnik dan suku bangsa pembuatnya. Mengingat bahwa bangsa Indonesia merupakan kesatuan dari berbagai etnik dan suku bangsa yang berdomisili di suatu wilayah yang terbentang dari Kota Sabang sampai dengan Kota Merauke, maka setiap benda cagar budaya tersebut juga menjadi sumber budaya bagi bangsa Indonesia. Di samping argumentasi itu, ada argumentasi lain yang mendukung pernyataan tersebut, yaitu bahwa budaya Indonesia merupakan wujud dari puncak-puncak budaya setiap etnik dan suku bangsa yang tercakup di dalam terminologi bangsa Indonesia.

Keberadaan benda cagar budaya merupakan bukti nyata atas sikap hidup dan mentalitas tertentu yang dimiliki oleh para somunitas leluhur pembangun benda cagar budaya tersebut. Dengan kata lain, benda cagar budaya mengandung sikap hidup dan mentalitas unggul yang dimiliki oleh para komunitas leluhur pendirinya. Sikap hidup dan mentalitas itu berupa sikap hidup yang penuh dengan nilai-nilai ketekunan, kerjasama, kegigihan, kerajinan, semangat kerja, pengorbanan, dan nilai-nilai luhur budaya lainnya. Oleh karena itu, benda cagar budaya diharapkan menjadi sumberdaya mental yang dapat memberi inspirasi dan sumber pembelajaran bagi setiap anak bangsa pada generasi penerus bangsa Indonesia. Dengan kata lain, setiap orang yang hidup sebagai generasi baru penerus bangsa Indonesia diharapkan dapat belajar mengenai mentalitas dan sikap hidup yang diwarnai dengan ketekunan, kerjasama, kegigihan, kerajinan, semangat, pengorbanan, dan nilai-nilai luhur budaya lainnya melalui benda cagar budaya yang ada.

Berdasarkan argumentasi sebagaimana dipaparkan di atas, keberadaan benda cagar budaya perlu dilestarikan. Keberadaan benda cagar budaya diharapkan dapat mendukung pewarisan nilai-nilai unggul budaya yang terkandung dalam benda cagar budaya tersebut, yakni pewarisan nilai-nilai budaya dan keunggulan dari generasi terdahulu kepada generasi penerus bangsa Indonesia.

Uraian di atas dapat digunakan untuk mengantar pemahaman atas Benda cagar budaya dalam kemasan secara definitif dalam batasan tertentu. Menurut Rokhmani (2007), Benda cagar budaya didefinisikan sebagai benda tinggalan masa lalu yang bernilai penting artinya bagi pengembangan ilmu pengetahuan, sejarah dan kebudayaan, sehingga perlu dilindungi dan dilestarikan demi memupuk jati diri bangsa dan kepentingan nasional.

\section{Keragaman Benda Cagar Budaya}

Benda cagar budaya hadir di dalam keberagaman. Sebagaimana disebutkan, benda cagar budaya sangat beragam dilihat dari aspek bahan, wujud, desain, bentuk, fungsi, periodisasi kurun waktu pembuatan serta latar belakang etnik dan budaya leluhur pembuatnya. Dari aspek bahan untuk membuatnya, keragaman benda cagar budaya terlihat dari adanya berbagai jenis bahan baku atau bahan dasar pembuat benda cagar budaya. Dengan demikian, Benda cagar budaya yang ditemukan saat ini ada yang terbuat dari bahan utama berupa batu, batu merah, keramik, perunggu, tembaga, dan kayu.

Candi Dieng, Candi Prambanan dan Candi Borobudur di Provinsi Jawa Tengah merupakan tiga buah contoh benda cagar budaya yang terbuat dari bahan utama batu. Candi Muara Takus di Provinsi Riau merupakan sebuah contoh benda cagar budaya yang terbuat dari bahan utama batu merah (bata) (Pemda Kab. Kampar, 2007). Masjid-masjid dan Surau-surau serta rumah-rumah gadang di Provinsi Sumatera Barat (BP3 
Batusangkar, 2005), banyak Pura di Provinsi Bali, Masjid Demak, Keraton Ngayogyakarta, Keraton Solo dan Keraton Cirebon di Provinsi Jawa Tengah, serta beberapa perahu hasil pengangkatan dari laut dan beberapa karya seni ukir patung asmat, terutama berupa Tongkat Utama di Bajun, merupakan contoh-contoh benda cagar budaya yang berbahan utama kayu (Schneebaum, 1985).

Dari aspek fungsi, keberadaan benda cagar budaya ada yang berfungsi sebagai sarana tempat ibadah (masjid, candi, pura, gereja, klentheng), ada yang bangunan gedung sebagai pusat pemerintahan (keraton), ada pula sebagai bangunan rumah tempat tinggal (rumah adat Kudus di Kudus, Rumah adat Joglo di Jogya dan Solo, Rumah Gadang di Padang). Di samping itu, ada pula benda cagar budaya yang berfungsi sebagai sarana transportasi, antara lain berupa kereta kencana, kapal dan perahu.

\section{Benda Cagar Budaya Terbuat Dari Kayu}

Benda cagar budaya terbuat dari kayu sering juga diterminologikan sebagai Benda Cagar Budaya yang Berbahan Kayu. Dengan mengikuti terminologi yang terakhir ini, kemudian muncul kependekan $\mathrm{BCBBK}$, untuk menggantikan frasa Benda Cagar Budaya yang Berbahan Kayu.

Sebagaimana disajikan pada subbab di atas, BCBBK memiliki keragaman dalam hal wujud, desain, bentuk, ukuran, fungsi dan latar belakang budaya masyarakat pendukung keberadaan BCBBK tersebut. Oleh karena itu, $B C B B K$ tertentu yang difungsikan sebagai sarana untuk mencapai tujuan yang sama, akan memiliki wujud, desain, bentuk dan ukuran yang berbeda, seirama dengan perbedaan lokasi tempat keberadaan BC $B B K$ tersebut. Perbedaan dalam hal wujud, desain, bentuk dan ukuran pada BC:BBK yang berfungsi sama, disebabkan oleh adanya keragaman latar belakang budava dan lingkungan alam tempat hidup etnik pendukung dan pembangun $\mathrm{BC}, \mathrm{BBK}$ tersebut.

Sebagai contoh, masjid-masjid yang berfungsi sebagai rumah ibadah dan pada saat ini berstatus sebagai BCBBK, akan memiliki desain, bentuk, ukuran scrta wujud arsitektur yang berbeda satu terhadap yang lain scirama dengan keberadaan BC BBK itu pada lingkungan hidup dan kebudayaan yang berbeda. Secara jelas dapat disaksikan, bahwa BC.BBK yang berfungsi sebagai masjid yang berada di Padang Parjaman akan memiliki desain, bentuk, ukuran serta wujud arsitektur yang berbeda terhadap BCBBK yang berfungsi sebagai masjid yang berada di Demak atau di Mataram Pulau Lombok.

Demikian pula BCBBK berfungsi sebagai rumah adat. Rumah-rumah adat yang berfungsi sebagai rumah tinggal dan pada saat ini berstatus sebagai BCBBK, akan memiliki desain, bentuk, ukuran serta wujud arsitektur yang berbeda satu terhadap yang lain seirama dengan keberadaan BCBBK itu pada lingkungan hidup dan kebudayaan yang berbeda. Secara jelas pula dapat disaksikan, bahwa $\mathrm{BCBBK}$ yang berfungsi sebagai rumah gadang yang berada di Sumatera Barat akan memiliki desain, bentuk, ukuran serta wujud arsitektur yang berbeda terhadap $B C B B K$ yang berfungsi sebagai rumah adat di Kudus, atau rumah adat Joglo di Yogya dan Solo atau juga rumah adat di Palangka Raya atau rumah adat di Tana Toraja.

BCBBK yang sudah jelas dari namanya sebagai bangunan terbuat dari kayu itu, ternyata bahwa jenis kayu yang digunakan sebagai bahan baku dalam membangun BCB itu juga berbeda-beda. Sudah tentu terbedakannya jenis-jenis kayu tersebut dapat diketahui apabila ada aktivitas pencermatan lebih lanjut terhadap berbagai jenis kayu sebagai bahan pembangun BCBBK. Sebagai contoh konkrit, rumah adat yang berstatus sebagai $B C B$ yang ada di Sumatra Barat, dibangun dari jenis kayu yang berbeda terhadap jenis kayu yang digunakan untuk membangun rumah adat di Jawa Tengah, atau rumah adat di Palangka Raya atau rumah adat di Sulawesi Tengah.

Perbedaan jenis kayu sebagai pembangun rumah adat BCBBK yang berada di wilayah tertentu (misalnya Padang Pariaman) terhadap jenis kayu pembangun rumah adat $B C B B K$ yang berada di wilayah yang lain (misalnya Jawa Tengah) itu merupakan suatu keniscayaan. Dapat dipahami, bahwa komunitas masyarakat pembangun rumah adat $\mathrm{BC} B \mathrm{BK}$ hanya akan menggunakan jenis kayu tertentu yang tumbuh di hutan yang berada di wilayah lokal atau regional sekitar tempat domisili mereka. Mengingat bahwa tempat domisili mereka itu berada di dalam lingkungan geografi tertentu dan kondisi geografi tertentu ini berimplikasi pada kondisi ekosistem tertentu yang ditandai dengan tingkat kesuburan tanah tertentu dan kondisi iklim tertentu, maka hutan dengan tipe tertentu pulalah yang tumbuh pada ekosistem tertentu tadi. Hutan tipe tertentu hanya akan menjadi tempat tumbuh bagi pohon-pohon jenis tertentu, dan dari pohon-pohon tertentu inilah yang akan menghasilkan jenis-jenis kayu tertentu. Meskipun demikian, komunitas masyarakat telah memiliki kemampuan yang hebat berdasarkan pengalaman hidup yang mengkristal menjadi kearifan lokal untuk memilih jenis kayu tertentu yang paling berkualitas di antara berbagai jenis kayu yang dihasilkan dari berbagai pohon yang tumbuh di hutan sebagai lingkungan hidup mereka. Kayu yang paling berkualitas yang disediakan oleh hutan alam di sekitar lingkungan hidup mereka inilah yang mereka pilih sebagai bahan bangunan yang kini berstatus sebagai BCBBK.

Berdasarkan atas dasar teori inilah, maka dapat dipahami bahwa kayu jenis tertentu yang berkualitas terbaik yang tumbuh pada lingkungan hutan alam di Pulau Sumatera saja yang digunakan untuk membangun rumah adat di Padang Pariaman atau Sumetera Barat pada umumnya. Jenis kayu yang dimaksud adalah kayu dipterokarpa. Demikian pula, dapat dipahami bahwa kayu jenis tertentu yang berkualitas terbaik yang tumbuh pada lingkungan hutan alam di Pulau Jawa saja yang digunakan untuk membangun rumah adat di Kudus atau Jawa Tengah pada umumnya. Jenis kayu yang dimaksud terakhir ini pada umumnya adalah kayu jati.

Berdasarkan pengalaman hidup yang mengkristal menjadi kearifan lokal, komunitas masyarakat telah memiliki kemampuan yang hebat untuk memilih jenis kayu tertentu yang paling berkualitas di antara berbagai jenis kayu yang tersediakan oleh alam. Beberapa parameter yang mereka gunakan sebagai dasar untuk memilih dan menentukan kualitas kayu ada lima katagori. Kelima katagori ini meliputi keawetan alami, kekuatan, kestabilan, dan tingkah kemudahannya untuk dikerjakan dengan alat pertukangan tradisional yang mereka miliki, serta keindahan alami kayu.

\section{Kerusakan Benda Cagar Budaya Yang Berbahan Kayu}

Meskipun $\mathrm{BCBBK}$ dibuat dari kayu yang paling awet dan paling berkualitas, $\mathrm{BC} B \mathrm{BK}$ ini akan mengalami kerusakan. Kerusakan ini pada umumnya berlangsung secara perlahan-lahan selama kurun waktu tertentu yang sangat panjang. Ada pula BCBBK yang mengalami kerusakan secara mendadak, yang disebabkan oleh bencana alam semisal oleh gempa bumi, atau angin puting beliung atau kebakaran. Istana Pagar Ruyung di Batusangkar merupakan satu contoh yang paling mutakhir tentang 
BCBBK yang mengalami kerusakan secara mendadak, yaitu oleh bencana kebakaran. Mengingat bahwa BCBBK pasti mengalami kerusakan baik secara perlahan-lahan maupun secara mendadak, maka BCBBK pada suatu saat tertentu perlu mengalami pemugaran.

Kayu merupakan komponen penyusun BCBBK. Oleh karena itu, kerusakan pada komponen kayu akan berakibat pada kerusakan BCBBK secara keseluruhan. Kerusakan kayu penyusun $\mathrm{BCBBK}$ sering juga disebut degradasi kualitas kayu atau kemunduran kualitas kayu. Sebutan ini berkait dengan kebersamaan antara proses penurunan mutu kayu dan proses kerusakan kayu. Kerusakan kayu dapat disebabkan oleh berbagai agen penyebab kerusakan. Kayu disadari sebagai bahan yang mudah mengalami kerusakan karena kayu merupakan bahan organik yang dapat mengalami dekomposisi.

Agen penyebab degradasi kayu ada yang berupa makhluk hidup, yang meliputi banyak jenis serangga (yaitu mencakup rayap dan kumbang penggerek serta penggerek laut) dan berbagai jenis jamur (meliputi jamur penoda, jamur pembusuk dan jamur pelapuk). Di samping itu, ada pula yang berupa faktor nir-biotis, yang meliputi (1) cuaca dengan anasir sinar matahari dan air hujan, (2) bahan kimia baik yang bersifat asam maupun bersifat basa, (3) beban mekanis, serta (4) panas dan api.

Jamur atau cendawan akan menginfeksi kayu bila kayu dalam kondisi basah atau berada dalam lingkungan yang berkelembatan tinggi yang cukup lama atau berhubungan langsung dengan tanah lembab. Jamur akan mengakibatkan kayu menjadi lapuk atau melunak dan busuk. Rayap-tanah yang berasal dari dalam tanah atau rayap-kayu-kering yang berasal dari udara dapat memakan kayu karena rayap tersebut menggunakan kayu dengan selulosanya sebagai sumber makanan dan habitat hidupnya. Kumbang bubuk juga demikian, karena mencari pati yang dikandung di dalam kayu sebagai sumber makanannya dan menyebabkan banyak lubang dan liang gerekan pada kayu, sehingga menurunkan kekuatan kayu. Bagi kayu yang berada di laut, penggerek kayu di laut juga akan menyebabkan lubanglubang gerekan di dalam dan di permukaan kayu yang juga akan menurunkan kekuatan kaỵu.

Cuaca dan Iklim berkomponen sinar matahari dan air hujan. Sinar maathari, terutama sinar ultra violet yang terkandung di dalamnya, menerpa BC. $\mathrm{BBK}$ dan akan merusak kayu meląlui proses depolimerisasi dan dekomposisi unsur-unsur penyusun kimia kayu, khususnya selulosa, hemiselulosa dan lignin. Bahan kimia, baik yang bersifat asam maupun bersifat basa, akan merusak kayu bila bahan ini mengenai kayu, Proses kerusakannya juga melalui proses reaksi depolimerisasi. Beban mekanis, baik beban statis maupun beban dinamis, yang membebani kayu lambat laun juga merusak kayu melalui proses kelelahan kayu. Sementara itu, panas merusak kayu juga melalui depolimerisasi kayu, sedangkan api merusak kayu melalui proses pengubahan kayu menjadi gas, cairan tar dan arang yang berproduk akhir berupa abu.

\section{Upaya Pelestarian Benda Cagar Budaya secara Otentik}

Dari uraian di atas, menjadi jelaslah bahwa sebagai salah satu jenis bahan dasar penyusun utama BCBBK, kayu merupakan bahan organik hasil pohon yang rentan terhadap kerusakan dan dekomposisi, baik yang disebabkan oleh unsur biotis maupun non-biotis. Oleh karena itu, upaya untuk mempertahankan keberadaan benda cagar budaya berbahan kayu perlu dilakukan. Upaya ini diwujudkan dalam aktivitas pelestarian benda cagar budaya. Pelestarian ini dilakukan dalam berbagai bentuk aktivitas. Aktivitas yang tercakup di dalamnya meliputi pemeliharaan, perawatan, dan pemugaran. Aktivitas pemeliharaan dilakukan antara lain dengan membersihkan BCBBK dari kotoran debu dan sampah. Aktivitas perawatan dilakukan antara lain dengan mengusahakan agar komponen penyusun BCBBK berada pada posisi yang seharusnya, sehingga fungsi komponen tersebut dapat diaktualisasikan secara penuh. Aktivitas pemugaran dilakukan dengan membangun kembali BCBBK sesuai dengan kondisinya yang asli. ()leh karena itu, aktivitas pemugaran dilakukan bila BCBBK itu mengalami kerusakan yang cukup parah. Di dalam aktivitas pemugaran, ada kemungkinan yang sangat besar untuk mengganti komponen tertentu atas $\mathrm{BCBBK}$ dan komponen ini berbahan kayu.

Penggantian kayu sebagai komponen $\mathrm{BC} \mathrm{BBK}$ dilakukan dengan berpedoman ketat terhadap persyaratan dan aturan-aturan tertentu. Hal ini dimaksudkan agar BCBBK hasil pemugaran terscbut tetap terjaga otentisitasnya atau keasliannya. L'ntuk mewujudkan otentisitas itu, pengyantian ti kayu bagi pemugaran $\mathrm{BCBBK}$ memerlukan persyaratan berupa keaslian jenis kayu, keaslian asal kayu, kesesuaian umur pohon'penghasil kayu. Di samping itu, penggantian kayu komponen $\mathrm{BCBBK}$ juga memenuhi beberapa aturan, yakni kesesuian sortimen kayu, kesesuaian bentuk dan ukuran kayu, serta kesesuaian proses pengolahan. Dengan kata lain, apabila kayu sebagai komponen penyusun bangunan $\mathrm{BCBBK}$ itu harus diganti karena mengalami kerusakan, maka kayu baru sebagai pengganti komponen penyusun bangunan $\mathrm{BCBBK}$ harus memiliki jenis yang sama, berasal dari wilayah yang sama, pohon penghasil kayu tersebut memiliki umur yang sama, sortimen kaỹu pengganti memiliki bentuk dan ukuran yang sama, serta kayu itu harus dikerjakan dengan alat yang sama dan metode yang sama dengan jenis kayu yang digantikannya.

Oleh karena penggantian kayu sebagai komponen BCBBK memerlukan otentisitas, maka aktivitas pemugaran harus dikelola secara seksama dan rapi. Di dalam konteks ini, pengelolaan terhadap aktivitas pemugaran selalu dilakukan dengan beberapa langkah secara berurutan. Pertama, proses pemugaran selalu. diawali dengan aktivitas observasi dalam rangka mengamati dan mencatat segala hal yang berkait dengan aktivitas pemugaran. Kedua, proses identifikasi dan analisis. Langkah kedua ini dimaksudkan untuk mengidentifikasi segala sesuatu, kemulian menganalisisnya agar pemugaran dapat dilakukan dengan menjaga otentisitas. Di dalam konteks ini, identifikasi dan analisis karu yang akan diganti merupakan hal ỵang sangat penting. Ketiga, adalah perencanaan penanganan. Di dalam perencanaan penanganan ini, seluruh sumber daya pemugaran didiskripsikan dan direncanakan. Keempat, pelaksanan aktivitas pemugaran tersebut.

\section{Sumbangan Ilmu Identifikasi Kayu di dalam Pemugaran BCBBK}

Dari uraian pada alinea di atas, sumbangan dan peran ilmu identifikasi kayu di dalam pemugaran BC.BBL mulai dapat dijelaskan. Pcmugaran BCBBK berorientasi pada otentisitas BC.BBK yang dipugar. ()tentisitas ini mencakup segala hal, termasuk pula mengenai keaslian kayu, baik mencakup jenis kayu, asal kayu, sortimen kayu, bentuk kayu, ukuran kalu. keberadaan pohon penghasil kayu, serta alat dan cara pengerjaan kavu terscbut. D) dalam konteks mengusahakan otenrisitas kayu komponen bangunan BC BBK, maka 
aktivitas identifikasi dan analisis kayu sangat berperan penting. Arti penting aktivitas ini bahkan ternyatakan di dalam langkah kedua dari empat langkah proses pemugaran $\mathrm{BCBBK}$.

Identifikasi kayu merupakan suatu aktivitas ilmiah vang berusaha untuk mengenal jenis dan nama ilmiah kayu. Dengan mengamati contoh uji berupa sepotong kecil kayu berukuran panjang 3 $\mathrm{cm}$ lebar $1 \mathrm{~cm}$ dan tebal $1 \mathrm{~cm}$, aktivitas identifikasi kayu akan dapat mengenal dan menetapkan jenis dan nama ilmiah suatu sortimen kavu, yakni sortimen kavu sebagai asal-muasal sepotong kecil kayu yang diamati tadi. Sebagaimana diketahui, bahwa kayu sebagai komponen penyusun bangunan $\mathrm{BCBBK}$ akan berbeda-beda dalam hal jenisnya, apalagi bila BCBBK itu berada pada lingkungan geografis yang berbeda pula. Di dalam pemugaran $\mathrm{BCBBK}$, pemahaman mengenai kayu menjadi sangat penting. Ilmu Identifikasi Kavu menjadi sarana untuk memahami kayu. Oleh karena itu, Ilmu identifikasi kayu akan dapat membantu mengusahakan otentisitas kayu yang akan diganti di dalam aktivitas pemugaran $\mathrm{BCBBK}$.

\section{Ilmu Identifikasi Kayu}

Kayu merupakan produk polimerisasi monomer gula sebagai hasil fotosintesis yang berlangsung pada daun sebagai organ tetumbuhan, yang dengan bantuan sinar matahari memadukan antara karbon dioksida dari udara dengan air dan garam mineral yang berasal dari tanah. Kayu terbentuk secara intensif pada tetumbuhan, terutama yang diklasifikasikan sebagai pohon. Proses polimerisasi ini membentuk unsur-unsur kimia berupa selulosa, hemiselulosa, lignin serta zat ekstraktif dan zat silika. Tiga unsur kimia yang pertama, yaitu selulosa, hemiselulosa dan lignin, membentuk ikatan kimiawi secara integral dan terwujudlah dinding sel kavu. Di dalam sel kayu terdapat ruang yang disebut sebagai rongga sel. Sel kayu yang jumlahnva berjuta-juta itu akhirnya membentuk benda padat yang kemudian disebut kavu. Dengan demikian, ketiga unsur itu secara bersama-sama membentuk kavu. Sementara itu, zat ekstraktif yang berada di dalam rongga sel kayu dan di dalam ruang interseluler kayu, dapat diekstraksi dan dikeluarkan dari benda padat kayu tanpa merusak kondisi fisik kavu

Secara lebih detil, unsur-unsur kimia tersebut membentuk sel-sel dan selsel inilah yang menjadi unsur sitologis bag kavu. Dengan demikian, kavu tersusun berjuta sel. sel sel ini secara fungsional mengelompok ke dalam empat macam jaringan, yaitu serat, pembuluh, parenkim dan jari-jari. Bagi kayu tertentu, di samping emat macam jaringan itu, masih ada tambahan satu jenis jaringan, yaitu jaringan saluran damar.

Serat merupakan jaringan sel kayu yang berfungsi untuk menghadirkan kekuatan dan konduksi pada kayu. Pembuluh merupakan jaringan sel yang berfungsi untuk konduksi (pengaliran) air di dalam kayu. Perenkim dan Jari-jari merupakan jaringan sel yng berfungsi sebagai tempat menyimpan karbohidrat di dalam kayu. Masing-masing jenis sel akan tampil dalam posisi yang khas di dalam kayu. Konfigurasi penampilan masingmasing jenis sel kayu ini akan membentuk pola atau struktur tertentu yang unik atau khas bagi jenis kayu tertentu. Jenis kayu yang berbeda akan menampilkan pola dan struktur yang berbeda pula.

Untuk memahami konfigurasi kayu yang terbentuk dari penampilan masingmasing sel ini di dalam kayu, berikut akan disajikan berbagai kemungkinan tentang penampilan masing-masing sel ini di dalam kayu. Penjajian mengenai penampilan selsel kayu akan diurutkan dengan urutan jarijari kayu, pembuluh kayu, parenkim kayu, serat kavu dan saluran damar.

Mengenai jari-jari kayu, ada berbagai kemungkinan penampilannya di dalam kayu. Penampilan itu berkait dengan dimensi jari-jari, keragaman ukuran jari-jari dan susunan jari-jari. Berdasarkan dimensi jari-jari, dikenal ada jari-jari berukuran besar, atau jari-jari berukuran sedang, atau jari-jari berukuran kecil. Berdasarkan keragaman ukuran jari-jari, dikenal ada jarijari berukuran seragam, atau jari-jari berukuran beragam. Penampilan jari-jari dikatakan beragam bila pada kayu itu terdapat jari-jari berdimensi besar yang hadir bersama dengan kehadiran jari-jari berukuran kecil. Berdasarkan susunan jarijari, dikenal ada jari-jariyang tersusun secara bertingkat dan jari-jari yang tersusun secara acak. Penampilan jari-jari dikatakan bertingkat bila pada jari-jari yang satu hadir pada posisi yang persis di bawah jarijari yang lain, sehingga posisi jari-jari itu secara keseluruhan membentuk baris yang teratur, baik ke arah vertikal maupun ke arah horizontal.

Uraian di atas disajikan mengenai unsur jari-jari kayu. Uraian berikutnya disajikan mengenai unsur pembuluh kavu.

Mengenai unsur pembuluh kayu, ada berbagai kemungkinan penampilannya di dalam kayu. Penampilan ini dibedakan berdasarkan katagori penyebaran dan susunan pembuluh. Berdasarkan h penyebaran pembuluh, pembuluh dapat dibedakan polanya menjadi tiga macam, yaitu pembuluh yang berpenyebaran tunggal, atau pembuluh yang berpenyebaran ganda, atau pembuluh yang berpenyebaran baris. Dalam konteks penyebaran baris ini, dibedakan lebih lanjut menjadi dua macam, yaitu pembuluh yang berpenyebaran baris lurus dan pembuluh yang berpenyebaran baris miring. Sementara itu, berdasarkan susunannya, pembuluh dibedakan menjadi tiga macam penampilan, yaitu pembuluh bersusunan baur, atau pembuluh bersusunan tata lingkar semu dan pembuluh bersusunan tata lingkar sejati.

Uraian di atas dipaparkan mengenai unsur pembuluh kayu. Uraian berikutnya disajikan mengenai unsur parenkim kayu.

Mengenai unsur parenkim kayu, ada berbagai kemungkinan penampilan parenkin ini di dalam kayu. Penampilan ini dibedakan berdasarkan dua katagori, yaitu parenkim yang bersentuhan dengan pembuluh dan parenkim yang tidak bersentuhan dengan pembuluh. Parenkim yang bersentuhan dengan pembuluh disebut sebagai parenkim paratrakheal, sedangkan parenkim yang tidak bersentuhan dengan pembuluh disebut parenkim apotrakheal.

Parenkim paratrakheal dibedakan lebih lanjut menjadi empat macam berdasarkan cara bersentuhannya dengan pembuluh. Keempat penampilan parenkim paratrakheal ini adalah parenkim abaksial, parenkim vasisentrik, parenkim aliform dan parenkim konfluen. Parenkim dikatakan berpenampilan sebagai parenkim abaksial, bila jaringan parenkim ini hanya bersentuhan secara tidak penuh menyelimuti seluruh lingkaran pembuluh. Parenkim dikatakan berpenampilan sebagai parenkim vasisentrik, bila jaringan parenkim ini bersentuhan secara penuh menvelimuti seluruh lingkaran pembuluh. Parenkim dikatakan berpenampilan sebagai parenkim aliform, bila jaringan parenkim ini tidak hanya bersentuhan secara penuh menvelimuti seluruh lingkaran pembuluh, tetapi juga memiliki sayap yang melebar pada kedua sisi tangensialnya. Parenkim dikatakan berpenampilan sebagai parenkim konfluen, bila jaringan parenkim ini tidak hanya bersentuhan secara penuh menyelimuti seluruh lingkaran pembuluh, dan memiliki sayap yang melebar pada kedua sisi tangensialnya, tetapi juga sayap yang melebar itu bergandengan dengan parekim aliform lainnya.

Uraian di atas mengenai parenkim 
paratrakheal. Uraian berikutnya mengenai parenkim apotrakheal.

Parenkim apotrakheal juga dibedakan lebih lanjut menjadi tiga macam penampilan berdasarkan kecenderungan keagregatannya. Ketiga macam penampilan parenkim apotrakheal ini meliputi parenkim difus, parenkin difus berkelompok, parenkin berbentuk pita. Parenkim berbentuk pita ini masih dibedakan lebih lanjut berdasarkan ukuran lebarnya menjadi tiga macam penampilan lagi, yaitu parenkim berbentuk pita sempit, parenkim berbentuk pita sedang dan parenkim berbentuk pita lebar.

Setelah penjelasan mengenai penampilan jari-jari, paembuluh dan parenkim sebagaimana disajikan di atas, berikut ini disajikan uraian mengenai serat kayu. Serat kayu juga merupakan hal yang penting di dalam idenfitikasi kayu.

Di dalam konteks serat kayu, penampilan serat kayu dibedakan menjadi empat macam berdasarkan orientasi sumbu panjangnya terhadap sumbu vertikal pohoh. Keempat penampilan serat kayu ini adalah serat berpenampilan lurus, serat berpenampilan miring, serat berpenampilan bergelombang, serat berpenampilan berpadu. Serat dinyatakan berpenampilan lurus bila sumbu panjang sel serat itu sejajar dengan sumbu longitudinal pohon. Serat dinyatakan berpenampilan miring bila sumbu panjang sel serat itu membantuk sudut tertentu terhadap sumbu longitudinal pohon. Serat dinyatakan berpenampilan bergelombang bila sumbu panjang sel serat itu memberi kesan berombah terhadap sumbu longitudinal pohon. Serat dinyatakan berpenampilan berpadu bila di dalam kayu itu terdapat perpaduan antara serat yang berpenampilan lurus dan serat yang berpenampilan miring secara berseling atau bergantian.

Ada lagi unsur kayu yang penting vaitu saluran damar. Saluran ini hanya terdapat pada kayu yang tergolong ke dalam kayu daun jarum. Golongan kayu jarum ini mencakup antara lain kayu pinus. Pada golongan kayu daun lebar, kehadiran saluran damar sangat jarang. Bila di dalam kayu daun lebar itu terdapat saluran damar, maka dapat dipastikan bahwa kayu tersebut adalah kayu yang tergolong di dalam keluarga dipterocarpaceae.

Seluruh uraian di atas diarahkan untuk mengemas pemahaman mengenai konfigurasi pola penampilan unsur-unsur kavu, baik dari unsur jari-jari, unsur pembuluh, unsur parenkim maupun serat. Konfigurasi pola penampilan unsur-unsur kayu ini kemudian disebut struktur kayu.
Dari struktur tersebut, dikenal lingkaran tahun, kayu awal dan kayu akhir serta kayu gubal dan kayu teras.

Di samping pola penampilan struktur kayu, identifikasi kayu juga memperhatikan ukuran dimensi unsurunsur kayu itu secara keseluruhan. Di dalam konteks dimensi unsur kayu ini, dikenal ada istilah yang disebut tekstur kayu.

Dalam konteks tekstur kayu, dikenal ada tiga macam tekstur kayu. Ketiga macam tekstur kayu ini meliputi kayu bertekstur halus, kayu bertekstur sedang dan kayu bertekstur kasar. Kayu dikatakan bertekstur halus bila ukuran diameter pembuluh adalah kurang dari 100 mikron. Kayu dikatakan bertekstur sedang bila ukuran diameter pembuluh adalah 100 s.d 300 mikron. Kayu dikatakan bertekstur kasar bila ukuran diameter pembuluh adalah lebih dari 300 mikron.

Penampilan masing-masing sel di dalam kayu akan membentuk pola atau struktur tertentu yang unik. Bersama dengan tekstur kayu yang tertentu, struktur yang unik pada kayu merupakan penciri atau penanda yang khas bagi kayu. Kombinasi berbagai penampilan masingmasing unsur kayu akan menghasilkan banyak kemungkinan struktur kayu. Berdasarkan struktur dan tekstur kayu tersebut, telah diidentifikasi keberadaan kayu di Indonesia yang terdiri atas 4000 jenis kayu.

Hal itu disebabkan karena jenis kayu yang berbeda akan menampilkan pola dan struktur yang berbeda pula. Dengan demikian, posisi masing-masing jenis sel dan pola keberadaannya akan menghasilkan wajah tertentu bagi kayu tertentu pula, yang berbeda antara kayu jenis yang satu terhadap jenis kayu yang lain. Dengan demikian, pola dan struktur kayu menjadi dasar bagi identifikasi kayu. Pembedaan jenis kayu ditentukan berdasarkan wajah kayu yang ditampilan oleh posisi dan pola struktur kayu.

Oleh karena itu, analisis mengenai jenis kayu yang menjadi bahan dasar BCBBK dapat dilakukan dengan mengamati struktur dan anatomi kavu pada contoh uji yang diambil dari BCBBK yang sedang dipugar. Struktur dan anatomi kayu tersebut kemudian dijadikan dasar untuk identifikasi jenis kayu. Identifikasi dilakukan dengan membandingkan antara struktur dan anatomi kayu BC.BBK di satu pihak dengan struktur dan anatomi kasu yang ada di katalog jenis kayu di pihak lain. Kesesuaian di antara keduanva akan digunakan sebagai dasar untuk mengenali dan menentukan jenis kayu vang rtimen digunakan sebagai komponen bangunan yang berstatus sebagai BCBKK yang sedang dipugar. Dengan demikian, sortimen kayu baru sebagai pengganti kayu yang rusak dapat ditentukan jenisnya. 区

\section{Daftar Pustaka.}

Balai Pelestarian Peninggalan Purbakala Batusangkar, 2005. Masjid-masjid kuno di Provinsi Sumatera Barat, Riau, dan Kepulauan Riau. Penerbit BP3 Batusangkar. Pagaruyung.

Pemda Kab. Kampar, 2007. Muara Takus, Situs Sejarah dan Budaya. Dinas Perhubungan, Pariwisata dan Seni Budaya. Bangkinang.

Rokhmani, S.K., 2008. Peningkatan Kapasitas SDM Bidang Kepurbakalaan. Makalah Rapat Kerja Tahun 2008 BP3 Batusangkar. Pekanbaru.

Schneebaum, T., 1985. Asmat Images. From the collection of the Asmat Moseum of Culture and Progress. Crosier Mission. Pendragon Press. Mennealpolis. New York.

\section{Bangunan kayu di Sumbawa}
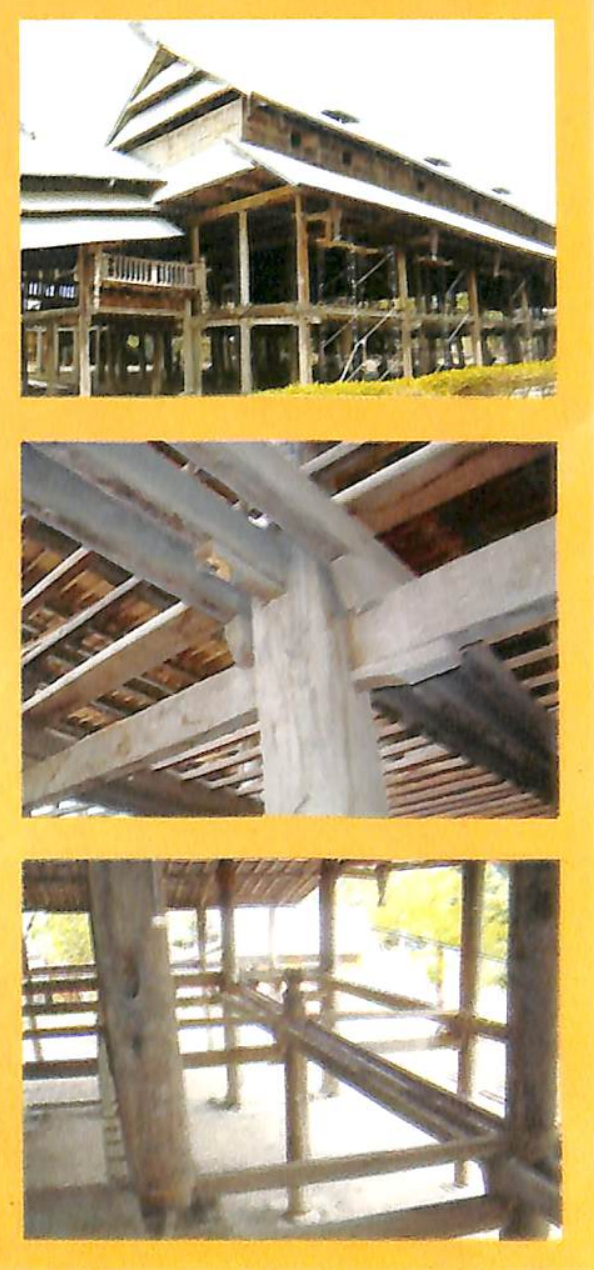